\title{
The effect of treating plum tree with Rovral (iprodion) and Euparen (dichlofluanid) on the content of soluble solids in fruit
}

\author{
HALINA BORECKA, HANNA BRYK and LECH MICHALCZUK \\ Research Institue of Pomology and Floriculture \\ Pomologiczna 18, 96-100 Skierniewice, Poland
}

(Received: April 6, 1988)

\begin{abstract}
The concentration of soluble solids in plum fruit varied and depended on the cultivar, year, and fungicide treatment. Plums from trees treated with Rovral (iprodion) contained in some case the lowest level of soluble solids, higher or equal levels were found in those sprayed with Euparen (dichlofluanid), and the highest concentration of soluble solids was in fruits from untreated trees. Explanation of this phenomenon is possible by looking for changes in photosynthesis of treated and untreated leaves. Fungicide treatment of some plum cultivars, particularly with Rovral, decreased the photosynthesis of the leaves.
\end{abstract}

\section{INTRODUCTION}

The chemical treatments of fruit trees growing in orchards are necessary for diseases control and increasing the quality of fruits. The influence of some fungicide treatments on physiological processes of plants has been noticed e.g. the treatment of apple trees by Topsin $M$ (thiophanate-methyl) increased the intensity of the red colour of fruit (Borecka, 1980); laboratory experiments with benomyl treatment of cucumber leafe discs demonstrated the benomyl stimulation of chlorophyll synthesis (Beckerson and Orm rod, 1986) and some other experiments with propiconazole, benomyl, tripherylthin hydroxide and dodine used on pecan leaves reduced net photosynthesis (Wood et al., 1985).

The experiments presented herein deal with the content of soluble solids in plum fruits. The finding that this content is lower in fruit from treated trees in explained as a probable effect of the decreased photosynthesis found in treated trees.

\section{MATERIAL AND METHODS}

The experiments were conducted for two years on 10-year-old plum trees growing at Prusy Exp. Station near Skierniewice. Rovral (iprodion) $50 \mathrm{WP}$ at a concentration of $0.1 \%$ and Euparen (dichlofluanid) $50 \mathrm{WP}$ at a concentration 
of $0.25 \%$ were applied twice in the orchard during the blossoming period and once 14 days before picking the fruit. Five trees of each of the tested cultivars were sprayed. Three plum cultivars were chosen: Wangenheim Prune, Italian Prune and Common Prune. Four samples, each containing $5 \mathrm{~kg}$ of fruit of each cultivar, were stored for 24 days at $2^{\circ} \mathrm{C}$. The soluble solids content in fruits was established before and after the storage period. Soluble solids were measured in 20 fruits of each cultivar using a refractometer.

In an attempt to explain the observed differences between the content of soluble solids in fruits from sprayed and unsprayed trees, observations on photosynthesis were conducted in Skierniewice Pomological Orchard. Ten leaves on five trees of two cultivars: Italian Prune and Stanley were treated (14 August) with Rovral 50 WP $-0.1 \%$ and Euparen 50 WP $-0.25 \%$ using a hand sprayer, and the relative photosynthesis rates of sprayed and unsprayed leaves were determined after two weeks. The relative photosynthesis rate was determined by the radioisotopic method of Shimishi (1969) modifies by Mika and Antoszewski (1972). Individual leaves were exposed for $30 \mathrm{~s}$ to an atmosphere containing ${ }^{14} \mathrm{CO}_{2}$ in a special plexiglass chamber. After exposure, discs $0.5 \mathrm{~cm}$ in diameter were cut-off from the leaf blade and immediately placed in scintillation vials containing $1 \mathrm{ml}$ of NCS tissue solubilizer (Amersham-Searle, Illinois, USA). After solubilization for $24 \mathrm{~h}$ at $60^{\circ} \mathrm{C}, 10 \mathrm{ml}$ of a scintillation coctail were added to each vial and radioactivity was measured using an ABAC SL-40 liquid scintillation counter (Intertechnique, France). The photosynthesis rate was expressed in relative units as $\mathrm{dpm}$ of ${ }^{14} \mathrm{C}$ assimilated by the leaf disc during $30 \mathrm{~s}$ of exposure. The measurements were performed on five individual leaves for each replication, ten replications were used; and the mean values were compared by Student's t-test.

\section{RESULTS AND DISCUSSION}

Experiments conducted in orchard on the control of plum diseases suggested that chemical treatment was also a factor affecting the content of soluble solids in plum fruit.

The fungicides used during the vegetative season in orchard decreased the soluble solids content in plum fruits, but their level also depended on the cultivar and year (Table 1). The difference between the level of soluble solids content in fruits picked from trees treated with iprodion and dichlofluanid depended mostly on the cultivar; in some e.g. Wangenheim Prune it was significant (first year of experiments), in others this difference appeard later during the storage period e.g. Italian Prune, and in still others, it was not noticed at all e.g. Common Prune in the same year of observation. The difference between the years suggests a significant role of weather conditions on the effect of fungicide treatment on the soluble solids content in fruits. Both years of observations also suggested the role of fungicide treatment on decreasing the 
Table 1

The influence of fungicide treatment in orchard on the soluble content in plum fruit, presented as mean percent

\begin{tabular}{|c|c|c|c|c|c|c|}
\hline \multirow{2}{*}{$\begin{array}{c}\text { Cultivar } \\
\text { and time } \\
\text { of treatment }\end{array}$} & \multicolumn{3}{|c|}{1983} & \multicolumn{3}{|c|}{1984} \\
\hline & $\begin{array}{c}\text { Euparen } \\
50 \mathrm{WP} \\
0.25 \%\end{array}$ & $\begin{array}{c}\text { Rovral } \\
50 \text { WP } \\
0.1 \%\end{array}$ & untreated & $\begin{array}{c}\text { Euparen } \\
50 \mathrm{WP} \\
0.25 \%\end{array}$ & $\begin{array}{c}\text { Rovral } \\
50 \text { WP } \\
0.1 \%\end{array}$ & untreated \\
\hline \multicolumn{7}{|l|}{ Wangenheim Prune } \\
\hline after picking & $19.9 b$ & $17.6 \mathrm{a}$ & $21.4 \mathrm{c}$ & $14.3 \mathrm{a}$ & $14.1 \mathrm{a}$ & $16.8 \mathrm{~b}$ \\
\hline after storage & $18.3 \mathrm{a}$ & $18.1 \mathrm{a}$ & $22.6 \mathrm{~b}$ & $12.8 \mathrm{a}$ & $13.6 \mathrm{ab}$ & $14.6 \mathrm{~b}$ \\
\hline \multicolumn{7}{|l|}{ Italian Prune } \\
\hline after picking & $16.5 \mathrm{a}$ & $16.6 \mathrm{a}$ & $19.4 b$ & $14.5 \mathrm{a}$ & $13.9 \mathrm{a}$ & $14.9 \mathrm{~b}$ \\
\hline after storage & $17.4 \mathrm{~b}$ & $16.3 \mathrm{a}$ & $18.6 \mathrm{c}$ & $15.2 \mathrm{a}$ & $14.5 \mathrm{a}$ & $14.3 \mathrm{a}$ \\
\hline \multicolumn{7}{|l|}{ Common Prune } \\
\hline after picking & $21.3 \mathrm{a}$ & $21.5 \mathrm{a}$ & $21.8 \mathrm{a}$ & $17.2 \mathrm{~b}$ & $13.5 \mathrm{a}$ & $19.0 \mathrm{c}$ \\
\hline after storage & $20.7 \mathrm{a}$ & $21.4 \mathrm{a}$ & $22.8 \mathrm{~b}$ & $17.1 \mathrm{~b}$ & $13.2 \mathrm{a}$ & $17.3 \mathrm{~b}$ \\
\hline
\end{tabular}

The differences were compared separately for cultivars and period $(\mathrm{LSD}=1 \%)$.

level of soluble solids in plum fruit. It is highly probable that the soluble solids content in fruit also depends on the photosynthesis of leaves. The intensity of photosynthesis was therefore measured in the next observations. The lowest level of photosynthesis was noticed in Italian Prune leaves treated with iprodion (Rovral), a bit higher in those treated with dichlofluanid (Euparen), and the highest was found in untreated leaves. A similar situation was noticed in cv. Stanley leaves but the difference between the tested fungicides was statistically insignificant (Table 2). The age of the leaves also influences photosynthesis (Shaffer et al., 1986; Raper and Kennedy, 1985). The leaves in the presented experiments were of the same age, growing on similar branches. The experiments were conducted when the fruits were unripe

Table 2

The influence of fungicide treatment on the photosynthesis of leaves two weeks after treatment, presented as $\mathrm{dpm} / \mathrm{min}$

\begin{tabular}{lccc}
\hline & \multicolumn{3}{c}{ Treatments } \\
\cline { 2 - 4 } \multicolumn{1}{c}{ Cultivars } & Euparen & Rovral & \\
& $50 \mathrm{WP}$ & $50 \mathrm{WP}$ & untreated \\
& $0.25 \%$ & $0.1 \%$ & \\
\hline Italian Prune & $22190 \mathrm{~b}$ & $16982 \mathrm{a}$ & $31991 \mathrm{c}$ \\
Stanley & $24037 \mathrm{~b}$ & $22463 \mathrm{~b}$ & $33099 \mathrm{c}$ \\
\hline
\end{tabular}

$\mathrm{LSD}=5 \%$. 
(28 August). This time was chosen because of the influence of fructification on photosynthesis (Schaffer et al., 1985). Wood's experiments on the influence of fungicides on photosynthesis conducted on pecan (Carya illonensis) leaves after 1 and 5 days without visible damage of leaves found reduced net photosynthesis similarly as in our experiments with plums. The differences among the cultivars were also significant, and the difference between the years showed the importance of weather conditions. This influence was seen not only during the growth of the plants, but also on the decomposition and disappearance of fungicide residues (W o o d et al., 1985). The anatomy of leaves seems to be a similarly important factor influencing the level of photosynthesis.

The aim of the presented experiments is to signalize the importance of the problem, an so they are necessarily of a preliminary nature.

\section{REFERENCES}

Beckers on D. W., Orm rod D. P., 1986. Investigating the cytokininlike properties of benomyl: laboratory growth studies. Pl. Dis. 70: 55-58.

Borecka H., 1980. Effect of hypobaric storage conditions on the quality of fruits and activity degradation of $\mathrm{BCM}$ fungicides in apples, strawberries and other fruits during storage. Report of PL-USDA nr. FG-Po-351 (JB 17): 194-211.

Mika A., Antoszewski R., 1972. Effect of leaf position and tree shape on the rate of photosynthesis in apple tree. Photosynthetica 6: 381-386.

Raper T. R., Kennedy R. A., 1985. Changes in photosynthetic characteristics during leaf development in Bing' sweet cherries. Hort. Sci. 20: 559.

Shaffer B., Barden J. A., Williams J. M., 1985. Partitioning of ${ }^{14} \mathrm{C}$-photosynthate in fruiting and deblossomed day-neutral strawberry plants. Hort. Sci. 20: 911-913.

Schaffer B., Barden J. A., Willi a ms J. M., 1986. Net photosynthesis, dark respiration, stomatal conductance, specific leaf weight, and chlorophyll content of strawberry plants as influenced by fruiting. Am. J. Soc. Hort. Sci. 111: 82-86.

Shimishi D., 1969. A rapid field method for measuring photosynthesis with labelled carbon dioxide. J. Exp. Bot. 20: 381-401.

Wood B. W., Payne J. A., Gottwald T. R., 1985. Inhibition of photosynthesis in pecan leaves by fungicides. Pl. Dis. 69: 997-998.

Wpływ opryskiwań śliw Rovralem (iprodion) i Euparenem (dichlofluanid) na zawartość ekstraktu w owocach

\section{Streszczenie}

Poziom ekstraktu w śliwkach zależy od odmiany, sezonu oraz stosowanego fungicydu. Śliwki pochodzące $\mathrm{z}$ drzew opryskiwanych Rovralem (iprodion) zawierały najmniej ekstraktu, owoce $\mathrm{z}$ drzew opryskiwanych Euparenem (dichlofluanid) zawierały wyższy lub równy poziom ekstraktu w porównaniu do owoców pochodzących $\mathrm{z}$ drzew opryskiwanych Rovralem; najwyższy procent ekstraktu zawierały owoce pochodzące $z$ drzew nie opryskiwanych fungicydami. Próbowano wytłumaczyć to zjawisko przez porównanie intensywności procesu fotosyntezy liści drzew opryskiwanych i nie opryskiwanych. Stosowanie fungicydów, zwłaszcza Rovralu, obniżało intensywność procesu fotosyntezy po upływie 14 dni od naniesienia fungicydu. 